\title{
Osteomalacia in a Case of Adult-Onset Bartter Syndrome
}

\author{
Rashid Naseem Khan ${ }^{1,2}$, Farhana Saba ${ }^{1}$ \\ ${ }^{1}$ Internal Medicine, Liaquat College of Medicine and Dentistry and Darul Sehat Hospital, Karachi, Pakistan \\ ${ }^{2}$ Patel Hospital, Karachi, Pakistan
}

Received: 23/10/2017

Accepted: $12 / 11 / 2017$

Published: 09/01/2017

How to cite this article: Khan RN, Saba F. Osteolmalacia in a case of adult-onset Bartter Syndrome. EJCRIM 2018;5: doi:10.12890/2018_000764.

Conflicts of Interests: The Authors declare that there are no competing interests.

This article is licensed under a Commons Attribution Non-Commercial 4.0 License

\section{ABSTRACT}

Bartter syndrome is a rare heterogeneous disease characterised by a deficiency in sodium and chloride absorption. Gain-of-function mutations in the CASR gene have been described in some patients with Bartter syndrome associated with hypocalcaemia and hypercalciuria. We describe a case of adult-onset Bartter syndrome with hypocalcaemia severe enough to cause osteomalacia.

\section{LEARNING POINTS}

- Bartter syndrome is one of the rare heterogenous diseases that present with electrolyte disturbances.

- Bartter syndrome type 5 also causes hypercalciuria which is not severe enough to cause osteomalacia.

- Patients with adult-onset Bartter syndrome should be screened promptly for osteomalacia to prevent pathological fractures and consequent complications.

\section{KEYWORDS}

Bartter syndrome, metabolic alkalosis, hypokalemia, hypocalcemia, osteomalacia, CaSR

\section{INTRODUCTION}

Bartter syndrome, first described by Bartter in 1962, comprises a set of autosomal recessive renal tubular disorders characterized by hypokalaemia, hypochloraemia, metabolic alkalosis and hyper-reninaemia with normal blood pressure ${ }^{[1]}$. Symptoms and severity vary between individuals but affected individuals generally have a mild form of the condition. It usually presents in young adulthood and is characterized by polyuria, fatigue, muscle cramps, spasms and tetany. Individuals may have low levels of parathyroid hormone, seizures and paraesthesias ${ }^{[2]}$. The calcium sensing receptor (CaSR) plays an important role in calcium homeostasis. Gain-of-function mutations in the CASR gene have been reported in some patients with Bartter syndrome associated with hypocalcaemia and hypercalciuria. Studies showed that these mutations result in receptor activation that is more severe than other gain-of-function mutations ${ }^{[3]}$. We describe a case of adultonset Bartter syndrome with hypocalcaemia severe enough to cause osteomalacia.

\section{CASE REPORT}

A 28-year-old woman was admitted to Darul Sehat Hospital with a 3-month history of generalized weakness and fatigue and severe left hip pain for 2 days.

The first episode of generalized physical aches, fatigue and left thigh pain had occurred 5 years previously when she was admitted to a different hospital and on laboratory work-up was found to have hypokalaemia. 
X-rays revealed a fracture of superior ramus of the left pubic bone and proximal parts of the right and left femurs (Figs. 1 and 2). She was conservatively managed for her fractures and her weakness improved with potassium replacement.

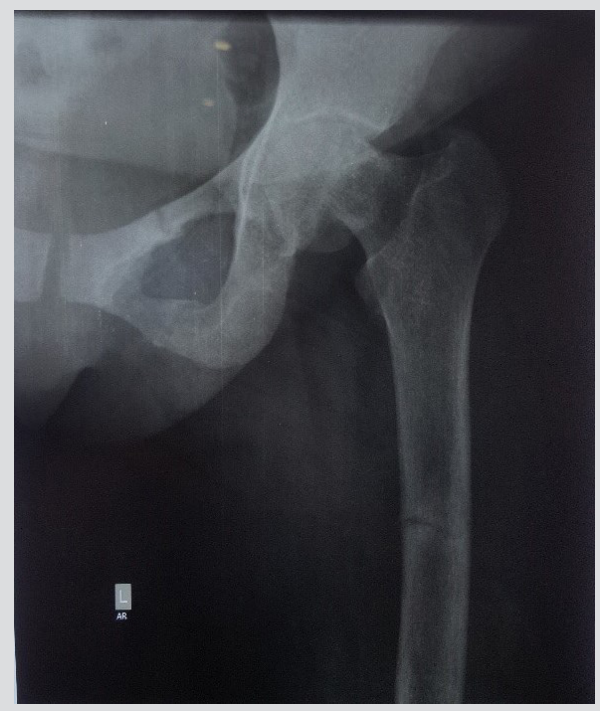

Figure 1. X-ray of the left femur and pelvis, February 2012

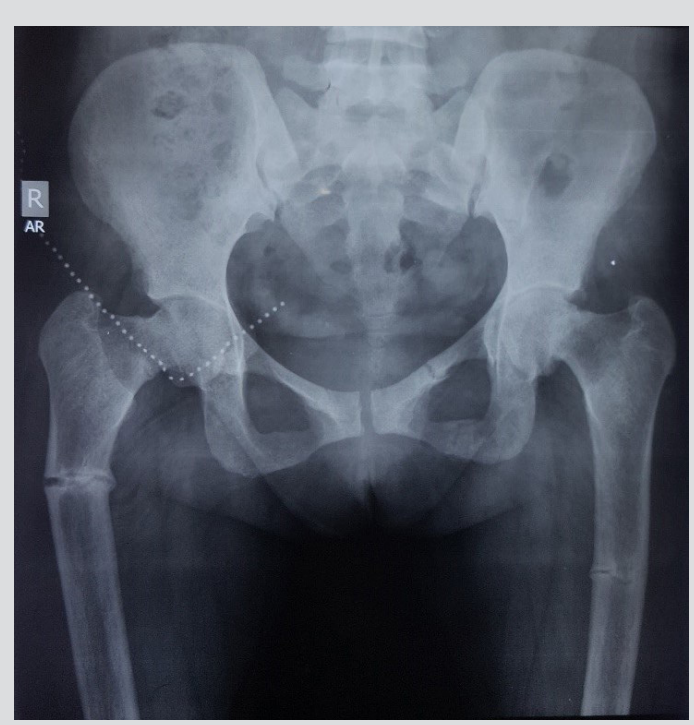

Figure 2. X-ray of the left femur and pelvis, September 2012

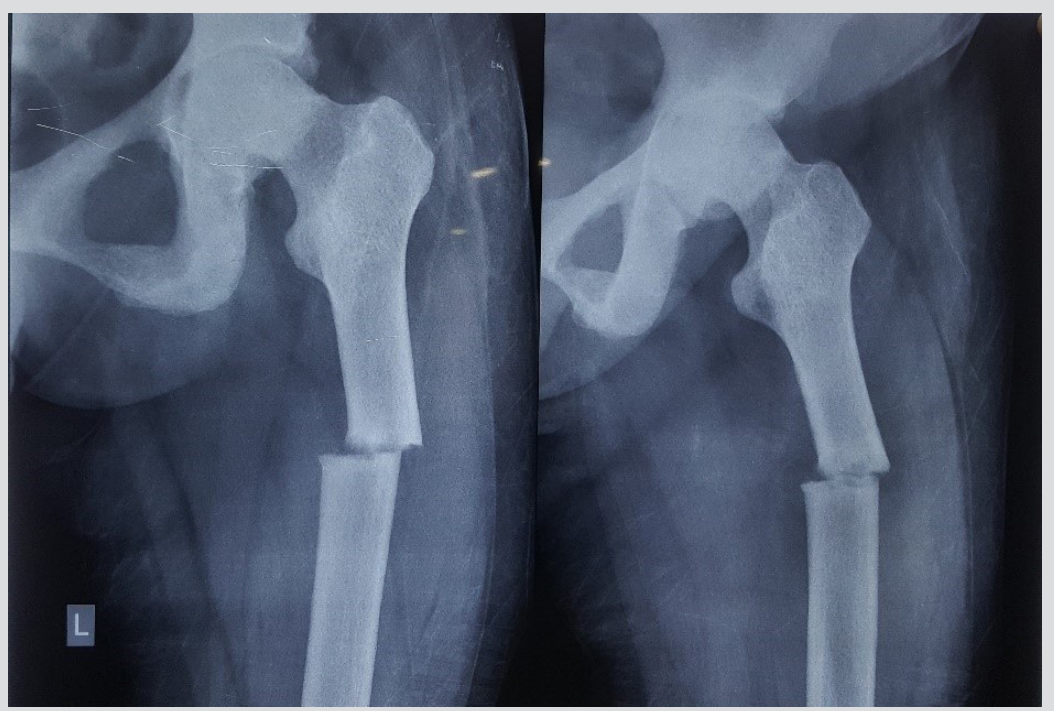

Figure 3. Fracture of the shaft of the left femur, April 2016

Thereafter she had been taking potassium supplements intermittently for her persistent hypokalaemia and calcium supplements but had never been thoroughly investigated. Now she had again developed the same but more severe symptoms. She denied taking laxatives and had no complaints of diarrhoea or vomiting. She had no significant family history and had normal dietary habits.

On examination, the patient appeared relatively well. She was $147 \mathrm{~cm}$ tall and a weighed $50 \mathrm{~kg}$. Her pulse rate was $98 / \mathrm{min}$, blood pressure was $100 / 70 \mathrm{mmHg}$, and respiration rate was $16 / \mathrm{min}$. Her left thigh was immobile and extremely tender, but there were no open wounds and no loss of sensation or vascular compromise. Examination of all other systems was unremarkable.

Laboratory findings included serum sodium of $136 \mathrm{mEq} / \mathrm{l}$, serum potassium of $2.6 \mathrm{mEq} / \mathrm{l}$, serum chloride of $108 \mathrm{mEq} / \mathrm{l}$, serum bicarbonate of $24 \mathrm{mEq} / \mathrm{l}$, serum calcium of $9.2 \mathrm{mg} / \mathrm{dl}$, serum phosphate of $1.94 \mathrm{mg} / \mathrm{dl}$ and alkaline phosphatase of $169 \mathrm{U} / \mathrm{l}$. Blood urea nitrogen was $16 \mathrm{mg} /$ $\mathrm{dl}$, serum creatinine was $0.9 \mathrm{mg} / \mathrm{dl}$ and serum magnesium was $2.3 \mathrm{mg} / \mathrm{dl}$. Electrocardiography showed T wave flattening. An x-ray of the left hip joint showed a fracture of the shaft of the left femur (Figs. 1-3). A DXA scan showed osteopaenia with a T-score of -1.9 (Tables 1 and 2 , Figs. 4 and 5). 


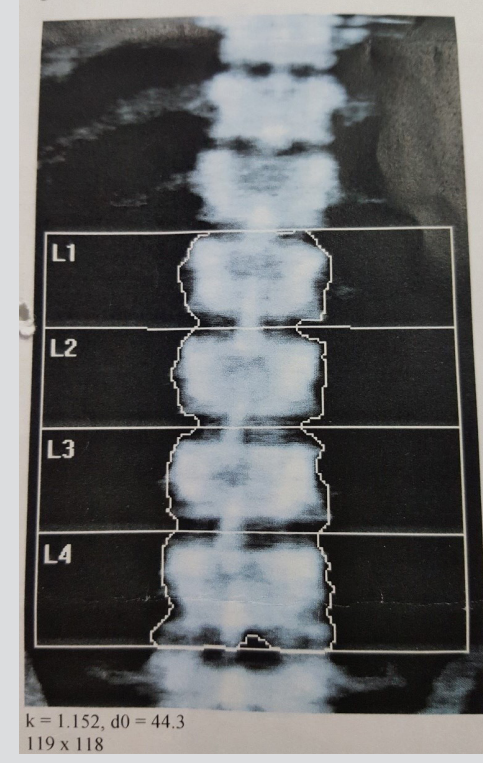

Figure 4. DXA scan, March 2016

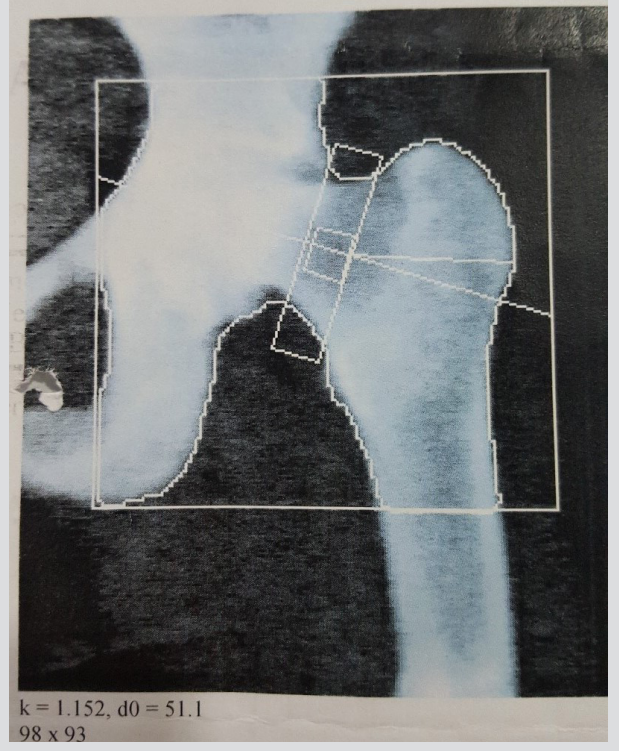

Figure 5. DXA scan, March 2016

\begin{tabular}{|l|l|l|l|l|l|l|}
\hline Region & Area $\left(\mathrm{cm}^{2}\right)$ & BMC $(\mathrm{g})$ & BMD $\left(\mathrm{g} / \mathrm{cm}^{2}\right)$ & T-score & Z-score & AM (\%) \\
\hline L1 & 11.61 & 17.66 & 1.520 & 5.4 & 5.6 & 168 \\
\hline L2 & 11.56 & 19.84 & 1.716 & 6.3 & 6.5 & 171 \\
\hline L3 & 12.58 & 22.25 & 1.769 & 6.2 & 6.5 & 167 \\
\hline L4 & 14.67 & 24.26 & 1.667 & 5.0 & 5.2 & 153 \\
\hline Total & 50.43 & 84.21 & 1.670 & 5.7 & 5.9 & 163 \\
\hline
\end{tabular}

Table 1. DXA results for the lumbar spine

$A M$, age matched; $B M C$, bone mineral content; $B M D$, bone mineral density.

\begin{tabular}{|l|l|l|l|l|l|l|}
\hline Region & Area $\left(\mathrm{cm}^{2}\right)$ & BMC $(\mathrm{g})$ & BMD $\left(\mathrm{g} / \mathrm{cm}^{2}\right)$ & T-score & Z-score & AM (\%) \\
\hline Neck & 3.63 & 2.22 & 0.610 & -2.2 & -1.9 & 75 \\
\hline Troch & 7.50 & 5.15 & 0.686 & -0.2 & -0.1 & 99 \\
\hline Inter & 16.18 & 13.58 & 0.839 & -1.7 & -1.6 & 77 \\
\hline Total & 27.31 & 20.95 & 0.767 & -1.4 & -1.3 & 83 \\
\hline Ward's & 0.95 & 0.49 & 0.512 & -1.9 & -1.3 & 77 \\
\hline
\end{tabular}

Table 2. DXA results summary

$A M$, age matched; $B M C$, bone mineral content; $B M D$, bone mineral density.

Serum vitamin D was $31 \mathrm{ng} / \mathrm{ml}$ (deficiency: <20 ng/ml). Serum PTH was 182.0 pg/ml (normal: 7-53 pg/ml), plasma renin was 148.0 ㅆIU/ $\mathrm{ml}$ (normal: 4.4-46.1 $\mu \mathrm{lU} / \mathrm{ml}$ erect) and serum aldosterone was $20 \mathrm{ng} / \mathrm{dl}$ (normal: $<15 \mathrm{ng} / \mathrm{ml}$ ). The 24-hour urinary excretion of sodium was $182 \mathrm{mEq}$, potassium $68 \mathrm{mEq}$, chloride $240 \mathrm{mEq}$, calcium $120 \mathrm{mg}$, protein $150 \mathrm{mg}$ and glucose $30 \mathrm{mg}$, and urine amount was 2,200 $\mathrm{ml}$. The urinary specific gravity was 1.010 and osmolality was $320 \mathrm{mOsm} / \mathrm{kg}$. The patient's previous laboratory findings when she first started having generalized physical aches and hypokalaemic episodes were serum calcium of $7.62 \mathrm{mg} / \mathrm{dl}$, serum phosphate of $2.48 \mathrm{mg} / \mathrm{dl}$, alkaline phosphatase of $166 \mathrm{U} / \mathrm{I}$ and serum potassium of $2.7 \mathrm{mEq} / \mathrm{l}$. The patient was treated with potassium chloride, calcium and vitamin $\mathrm{D}$ supplements. Her serum potassium concentration improved from $2.6 \mathrm{mEq} / \mathrm{l}$ to $3.1 \mathrm{mEq} / \mathrm{l}$, her muscle strength rapidly recovered and she did well. Her femur fracture was conservatively managed and also began to heal. 


\section{DISCUSSION}

More than 230 different germline mutations of the CaSR, which is encoded by the CASR gene located on chromosome 3q21.1, have been reported. These mutations may cause severe loss of CaSR function associated with hypocalcaemic disorders such as Bartter syndrome type 5 , which is characterised by renal salt wasting, hypokalaemic alkalosis and hyper-reninaemic hyperaldosteronism ${ }^{[4]}$.

Four genes have been identified which can cause Bartter syndrome: SLC12A2, encoding the sodium-potassium-chloride cotransporter NKCC2; KCNJ1, encoding the ROMK1 potassium ion channel; CLCNKB, encoding the CIC-Kb basolateral chloride ion channel; and BSND, encoding barttin, a regulatory subunit required for basolateral chloride channel targeting to the membrane. Bartter type 5 is distinguished from the other types by its autosomal dominant transmission and the presence of hypocalcaemic hypercalciuria ${ }^{[5]}$.

Several studies have described the pathophysiology of this syndrome (Tables 3 and 4). A few cases have been reported, but Bartter syndrome with hypocalcaemia severe enough to cause osteomalacia has not previously been reported.

\begin{tabular}{|l|l|l|}
\hline Author & Year & Defect \\
\hline Gardner et al. ${ }^{[6]}$ & 1970 & $\begin{array}{c}\text { Primary defect in membrane transport, based on studies of sodium content } \\
\text { and outflux of erythrocytes }\end{array}$ \\
\hline${\text { Ramos et al. }{ }^{[7]}}$ & 1980 & $\begin{array}{c}\text { Defect in chloride reabsorption in the ascending thick limb of Henle's loop, } \\
\text { leading to hypokalaemia }\end{array}$ \\
\hline Baehler et al. ${ }^{[8]}$ & 1980 & $\begin{array}{c}\text { Primary defect in the reabsorption of sodium chloride in the ascending limb } \\
\text { and not renal potassium wasting }\end{array}$ \\
\hline
\end{tabular}

Table 3. Pathophysiology

\begin{tabular}{|l|l|l|}
\hline Author & Year & Case report \\
\hline Vezzoli et al. ${ }^{[9]}$ & 2006 & $\begin{array}{r}\text { Case of twin sisters with autosomal dominant hypocalcaemia due to a K29E } \\
\text { activating mutation of the CASR gene and Bartter syndrome. They had } \\
\text { a mild phenotype }\end{array}$ \\
\hline Choi et al. ${ }^{[10]}$ & 2015 & Patient with autosomal dominant hypocalcaemia with Bartter syndrome \\
\hline
\end{tabular}

Table 4. Case reports

\section{CONCLUSION}

In this case, the patient was diagnosed with adult-onset Bartter syndrome because of hypokalaemia, relative hypotension, increased renin activity and increased aldosterone level. Following treatment, serum potassium concentration improved and the patient's muscle strength rapidly recovered. The osteomalacia caused by the disease and found at the same time was also treated and the patient was doing well by her next follow-up visit.

\section{REFERENCES}

1. FC Bartter, P Pronove, JR Gill Jr, RC MacCardle. Hyperplasia of the juxtaglomerular complex with hyperaldosteronism and hypokalemic alkalosis. A new syndrome. Am J Med 1962;33:811-828

2. Bartter's syndrome. https://rarediseases.org/rare-diseases/bartters-syndrome.Accessed: 20 June 2017.

3. Vargas-Poussou R, Huang C, Hulin P, Houillier P, Jeunemaître X, Paillard M, et al. Functional characterization of a calcium-sensing receptor mutation in severe autosomal dominant hypocalcemia with a Bartter-like syndrome. J Am Soc Nephrol 2002;13:2259-2266.

4. Hannan FM, Babinsky, Thakker RV. Disorders of the calcium-sensing receptor and partner proteins: insights into the molecular basis of calcium homeostasis. J Mol Endocrinol 2016;57:R127-R142.

5. Guay-Woodford LM. Hereditary nephropathies and developmental abnormalities of the urinary tract. In: Cecil RLF, Goldman L, Schafer Al, editors. Goldman's Cecil Medicine. 25th ed. Elsevier Health Sciences; 2012, pp. 801-802.

6. Gardner J, Lapey A, Simopoulos AP, Bravo E. Evidence for a primary disturbance of membrane transport in Bartter's syndrome and Liddle's syndrome [Abstract]. J Clin Invest 1970;49:32.

7. Ramos E, Hall-Craggs M, Demer LM. Surreptitious habitual vomiting simulating Bartter's syndrome. JAMA 1980;243:1070-1072.

8. Baehler RW, Work J, Kotchen TA, McMorrow G, Guthrie G. Studies on the pathogenesis of Bartter's syndrome. Am J Med 1980;69:933-938.

9. Vezzoli G, Arcidiacono T, Paloschi V, Terranegra A, Biasion R, Weber G, et al. Autosomal dominant hypocalcemia with mild type 5 Bartter syndrome. J Nephrol 2006;19:525-528.

10. Choi KH, Shin $\mathrm{CH}$, Yang SW, Cheong H. Autosomal dominant hypocalcemia with Bartter syndrome due to a novel activating mutation of calcium sensing receptor, Y829C. Korean J Pediatr 2015;58:148-153. 